Supporting Information

\title{
Structure Transition and Swapping Pattern of Clathrate Hydrates Driven by External Guest Molecules
}

\author{
Sun-Hwa Yeon, Jiwoong Seol and Huen Lee*
}

Department of Chemical and Biomolecular Engineering, Korea Advanced Institute of Science and Technology, 373-1 Guseong-dong, Yuseong-gu, Daejeon 305-701, Korea.

"Corresponding author. Tel. : 82-42-869-3917 Fax : 82-42-869-3910

E-mail address : h_lee@ kaist.ac.kr 


\section{Table of Contents}

\section{General Information}

Reagents

Sample Preparation

\section{Experimental Section}

1. X-ray Powder Diffraction

Figure S1. XRD data of the mixed $\mathrm{CH}_{4}+\mathrm{C}_{2} \mathrm{H}_{6}$ hydrate formed from $20 \mathrm{~mol} \% \mathrm{C}_{2} \mathrm{H}_{6}$ balanced $\mathrm{CH}_{4}$.

\section{Raman Spectroscopy}

Figure S2-1. Raman spectra of the mixed $\mathrm{CH}_{4}+\mathrm{C}_{2} \mathrm{H}_{6}$ hydrate before and after $\mathrm{CH}_{4}$ replacement :(a) the mixed $\mathrm{CH}_{4}+\mathrm{C}_{2} \mathrm{H}_{6}$ hydrate formed from 10 mol\% $\mathrm{C}_{2} \mathrm{H}_{6}$ balanced $\mathrm{CH}_{4}(272.15 \mathrm{~K}, 55$ bar $)$ and hydrate replaced by 117 bar $\mathrm{CH}_{4}$ at $274.15 \mathrm{~K}$.:(b) the mixed $\mathrm{CH}_{4}+\mathrm{C}_{2} \mathrm{H}_{6}$ hydrate formed from 20 mol\% $\mathrm{C}_{2} \mathrm{H}_{6}$ balanced $\mathrm{CH}_{4}(272.15 \mathrm{~K}, 55$ bar $)$ and hydrate replaced by 117 bar $\mathrm{CH}_{4}$ at $274.15 \mathrm{~K}$.

Figure S2-2. Raman spectra of the mixed $\mathrm{CH}_{4}+\mathrm{C}_{2} \mathrm{H}_{6}$ hydrate before and after $\mathrm{CH}_{4}$ replacement : (a) the $\left[\mathrm{MCH}(2.8 \mathrm{~mol} \%)+\mathrm{CH}_{4}\right]$ hydrate $(272.15 \mathrm{~K}, 50$ bar $)$ and hydrate replaced by 110 bar $\mathrm{CH}_{4}$ at $274.15 \mathrm{~K}$.and hydrate replaced by 117 bar $\mathrm{CH}_{4}$ at $274.15 \mathrm{~K}$. (b) the [isopentane $(2.8$ mol\% $\left.)+\mathrm{CH}_{4}\right]$ hydrate $(272.15 \mathrm{~K}, 50$ bar $)$ and hydrate replaced by 110 bar $\mathrm{CH}_{4}$ at $274.15 \mathrm{~K}$.

\section{High Power-Decoupling ${ }^{13} \mathrm{C}$ NMR spectroscopy}

4. Phase stability conditions

Figure S4-1 Hydrate phase boundary of pure $\mathrm{CH}_{4}$, mixed $\mathrm{CH}_{4}+$ isopentane, and mixed $\mathrm{CH}_{4}+\mathrm{MCP}$ hydrates.

Figure S4-2 Phase diagram of $\mathrm{CH}_{4}, \mathrm{C}_{2} \mathrm{H}_{6}$, mixed $\mathrm{CH}_{4}+\mathrm{C}_{2} \mathrm{H}_{6}$ (feed gas : $\mathrm{C}_{2} \mathrm{H}_{6} 10$ mol\% balanced $\mathrm{CH}_{4}$ ), 
and mixed $\mathrm{CH}_{4}+\mathrm{C}_{2} \mathrm{H}_{6}$ (feed gas : $\mathrm{C}_{2} \mathrm{H}_{6} 20$ mol\% balanced $\mathrm{CH}_{4}$ ) hydrates.

5. Gas Chromatography

Table S5-1 Compositions before and after replacement in hydrate phase

Table S5-2 Gas phase compositions after replacement 


\section{General Information}

\section{Reagents}

$\mathrm{CH}_{4}+\mathrm{C}_{2} \mathrm{H}_{6}$ gas mixtures (10 mol\% $\mathrm{C}_{2} \mathrm{H}_{6}$ balanced $\mathrm{CH}_{4}$, and $20 \mathrm{~mol} \% \mathrm{C}_{2} \mathrm{H}_{6}$ balanced $\mathrm{CH}_{4}$ ) and $\mathrm{CH}_{4}$ gas with a purity of $99.9 \mathrm{~mol} \%$ used for the present study was supplied by World Gas (Korea). The water with an ultrahigh purity was supplied from Merck (Germany). Isopentane (2-methylbutane) of $99.5 \%$ and methylcyclohexane (MCH) of $99 \%$ from Aldrich Chemical CO., Inc. were used without any further purification.

\section{Sample Preparation}

The experimental procedure was followed. The mixed $\mathrm{CH}_{4}+\mathrm{C}_{2} \mathrm{H}_{6}$ hydrate samples of sII obtained from feed gas $\mathrm{C}_{2} \mathrm{H}_{6} \quad 10 \mathrm{~mol} \%$ and $20 \mathrm{~mol} \%$ balanced $\mathrm{CH}_{4}$ were prepared in a mechanically stirred reactor having the volume of $150 \mathrm{~cm}^{3}$ at $55 \mathrm{bar}, 272.15 \mathrm{~K}$. The prepared sII hydrate was finely (100-150 $\square$ mesh) pulverized in a mortar and pestle under liquid nitrogen temperature. The new reactor cell having the volume of $150 \mathrm{~cm}^{3}$ was filled with $5 \mathrm{~g}$ of powdered ice particles of prepared sII hydrate and then pressurized with a pure methane gas of 25 bar and 117 bar, respectively, and this pressurized cell was kept at $274.15 \mathrm{~K}$ for 3 days for the reaction of $\mathrm{CH}_{4}$ replacement. The $\mathrm{MCH}(2.8 \mathrm{~mol} \%)+\mathrm{CH}_{4}$ (help gas, 50 bar) hydrate sample for $\mathrm{sH}$ were prepared in a mechanically stirred reactor having the volume of $150 \mathrm{~cm}^{3}$ at $272.15 \mathrm{~K}$. A mechanical stirrer agitated the ice particles during the entire formation process to provide a fresh surface to participate in the formation of gas hydrates. When the formation process of $\mathrm{MCH}(2.8 \mathrm{~mol} \%)+\mathrm{CH}_{4}$ (help gas, 50 bar) hydrate sample was completed, the formed $\mathrm{sH}$ hydrate was finely powdered in the liquid nitrogen vessel after venting residual $\mathrm{CH}_{4}$ gas in the hydrate reactor cell. In order to replace $\mathrm{CH}_{4}$ gas, the formed sH hydrate samples was pressurized with $\mathrm{CH}_{4}$ gas of 25 bar and 110 bar, respectively, in which the reactor cell was closed. For the solid-state ${ }^{13} \mathrm{C}$ NMR spectra experiments, the hydrate sample was powdered under liquid nitrogen temperature condition, which was then placed under atmospheric condition in a $4 \mathrm{~mm}$ o.d. zirconia rotor loaded into a variable temperature probe. The NMR rotor was sealed by rotor cap after the hydrate sample was packed. The working temperature for NMR experiment was $-70{ }^{\circ} \mathrm{C}$. During the period for establishing the stable NMR operation the hydrate samples might be a little dissociated and thus the frequent appearance of the gas peak in the spectra seems to be unavoidable from the present NMR technique. 


\section{Experimental Section}

\section{X-ray Powder Diffraction}

The structures of sII hydrate hydrate were determined by a D/max-RB (Rigaku) diffractometer with $\mathrm{CuK} \alpha 1$ radiation $(\lambda=1.5406 \AA)$ and observed 24 diffraction peaks at 1 bar and $123.15 \mathrm{~K}$. The X-ray diffraction data were collected by step mode with a fixed time of $3 \mathrm{~s}$ and a step size of $0.03^{\circ}$ over $2 \mathrm{hr}\left(10\right.$ to $65^{\circ}$ in $\left.2 \theta\right)$ at 1 bar and $123.15 \mathrm{~K}$.

Figure S1. XRD data of the mixed $\mathrm{CH}_{4}+\mathrm{C}_{2} \mathrm{H}_{6}$ hydrate (sII) formed from 20 mol\% $\mathrm{C}_{2} \mathrm{H}_{6}$ balanced $\mathrm{CH}_{4}(\mathrm{a}=17.5 \AA)$.

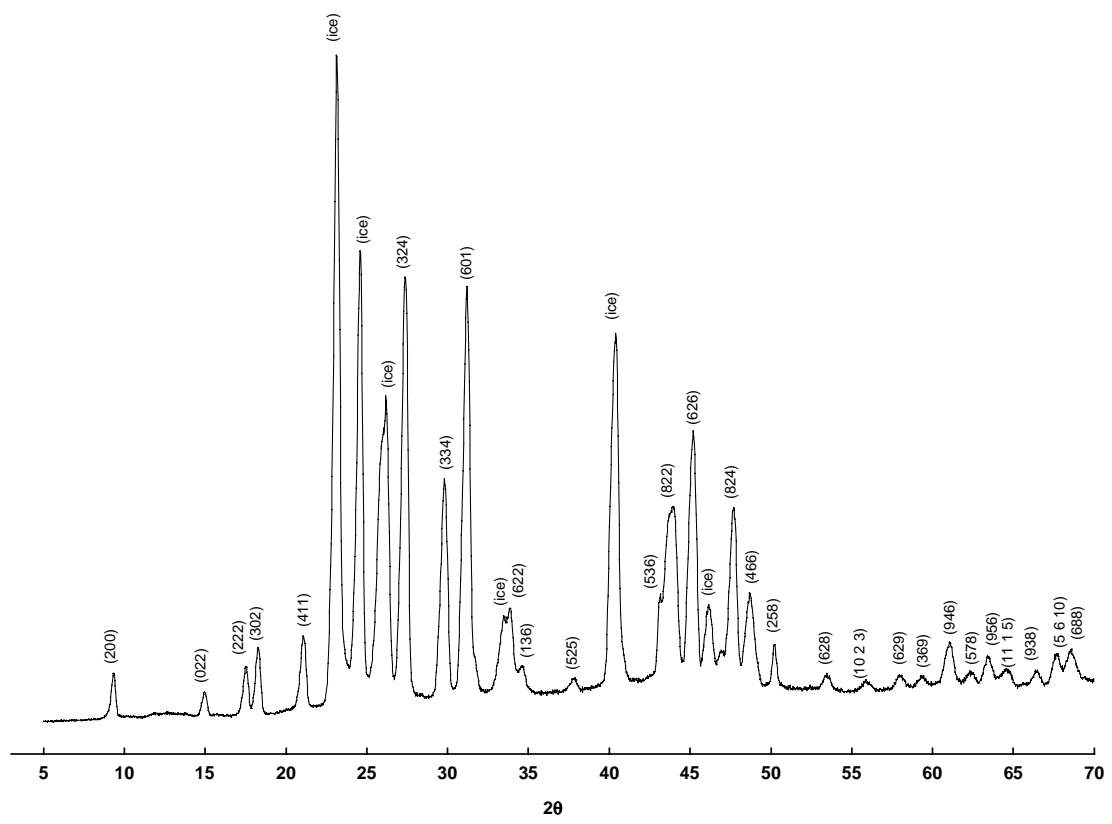




\section{Raman Spectroscopy}

The Raman spectra were obtained using a SPEX 1404p single grating Raman spectrometer, with a CCD detector cooled by liquid $\mathrm{N}_{2}$, using the focused $488 \mathrm{~nm}$ line of an Ar-ion laser for excitation at 120 bar and $270.0 \mathrm{~K}$. The laser intensity was typically $300 \mathrm{~mW}$.

Figure $\mathrm{S}$ 2-1. Raman spectra of the mixed $\mathrm{CH}_{4}+\mathrm{C}_{2} \mathrm{H}_{6}$ hydrate before and after $\mathrm{CH}_{4}$ replacement :(a) the mixed $\mathrm{CH}_{4}+\mathrm{C}_{2} \mathrm{H}_{6}$ hydrate formed from $10 \mathrm{~mol} \% \mathrm{C}_{2} \mathrm{H}_{6}$ balanced $\mathrm{CH}_{4}(272.15 \mathrm{~K}, 55$ bar) and hydrate replaced by 117 bar $\mathrm{CH}_{4}$ at $274.15 \mathrm{~K}$. :(b) the mixed $\mathrm{CH}_{4}+\mathrm{C}_{2} \mathrm{H}_{6}$ hydrate formed from $20 \mathrm{~mol} \%$ $\mathrm{C}_{2} \mathrm{H}_{6}$ balanced $\mathrm{CH}_{4}\left(272.15 \mathrm{~K}, 55\right.$ bar) and hydrate replaced by 117 bar $\mathrm{CH}_{4}$ at $274.15 \mathrm{~K}$.
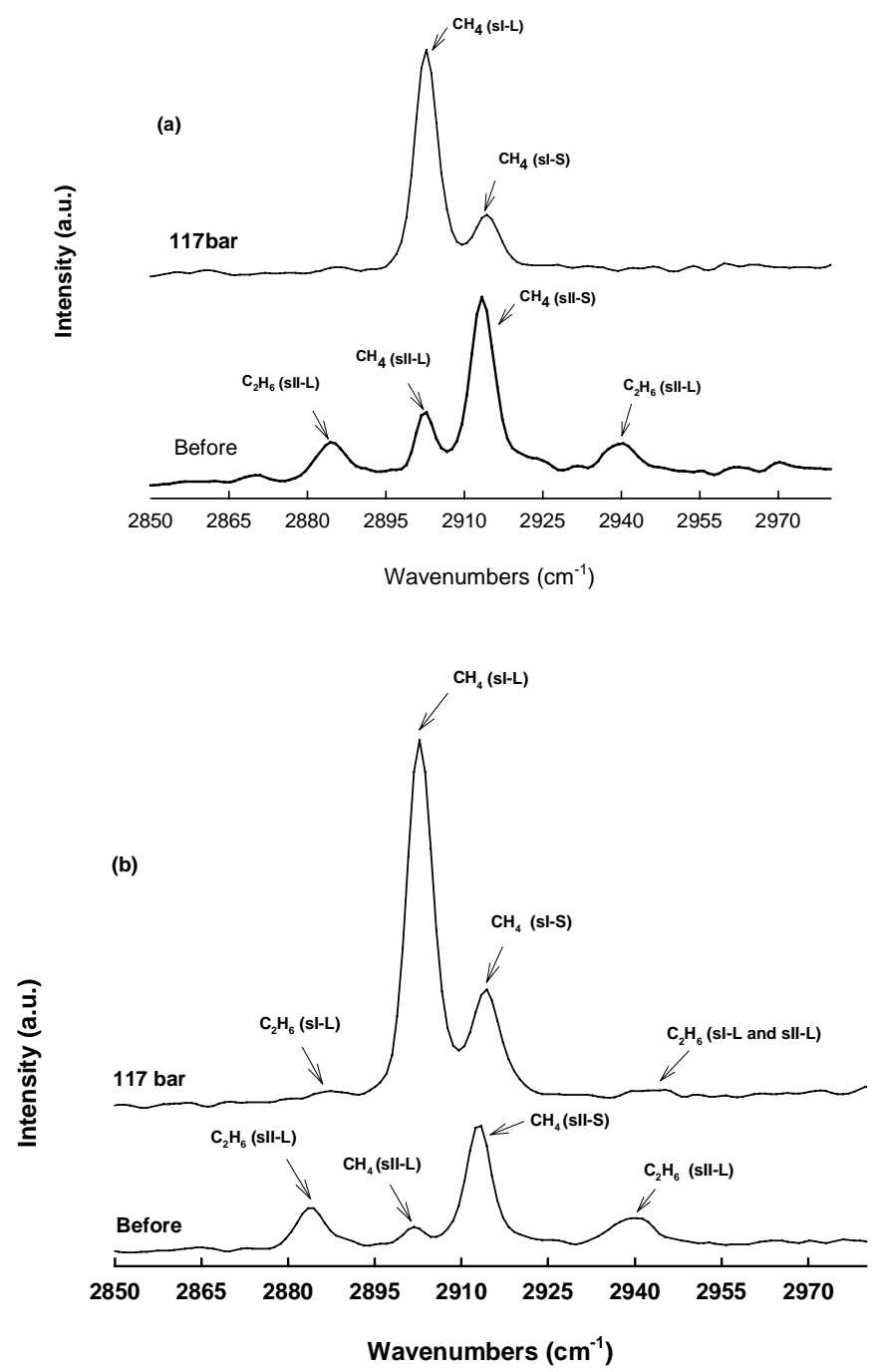
Figure S 2-2. Raman spectra of the mixed $\mathrm{CH}_{4}+\mathrm{C}_{2} \mathrm{H}_{6}$ hydrate before and after $\mathrm{CH}_{4}$ replacement : (a) the $\left[\mathrm{MCH}(2.8 \mathrm{~mol} \%)+\mathrm{CH}_{4}\right]$ hydrate $(272.15 \mathrm{~K}, 50 \mathrm{bar})$ and hydrate replaced by 110 bar $\mathrm{CH}_{4}$ at $274.15 \mathrm{~K}$.and hydrate replaced by 117 bar $\mathrm{CH}_{4}$ at $274.15 \mathrm{~K}$. (b) the [isopentane $(2.8 \mathrm{~mol} \%)+\mathrm{CH}_{4}$ ] hydrate $\left(272.15 \mathrm{~K}, 50\right.$ bar) and hydrate replaced by 110 bar $\mathrm{CH}_{4}$ at $274.15 \mathrm{~K}$.
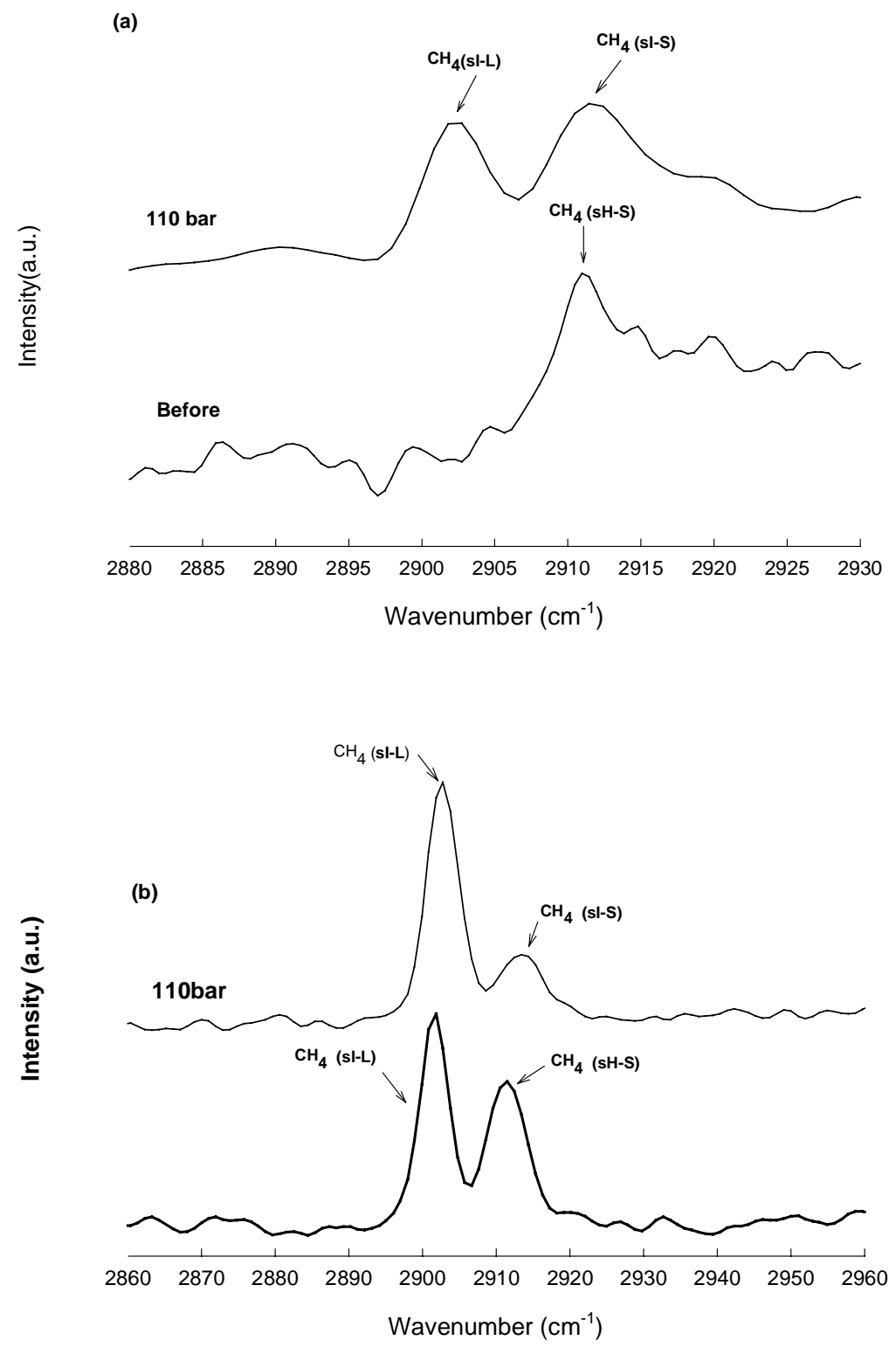


\section{High Power-Decoupling ${ }^{13} \mathrm{C}$ NMR spectroscopy}

To identify hydrate structure and guest distribution, a Bruker DSX $400 \mathrm{MHz}$ solid-state NMR spectrometer was used in this study. The powdered samples were placed in a $4 \mathrm{~mm}$ o.d. zirconia rotor loaded into a variable temperature probe. All ${ }^{13} \mathrm{C}$ NMR spectra were recorded at a Larmor frequency of $100.6 \mathrm{MHz}$ with magic angle spinning (MAS) at about $3 \mathrm{kHz}$. A pulse length of $2 \square$ and pulse repetition delay of 40s under proton decoupling were employed with a radio frequency field strength of $50 \mathrm{kHz}$, corresponding to $5 \mu \mathrm{m} 90^{\circ}$ pulses. The downfield carbon resonance peak of adamantine, assigned a chemical shift of $38.3 \mathrm{ppm}$ at $300 \mathrm{~K}$, was used as an external chemical shift reference.

\section{Phase stability conditions}

Figure S4-1. Hydrate phase boundary of pure $\mathrm{CH}_{4}$, mixed $\mathrm{CH}_{4}+$ isopentane, and mixed $\mathrm{CH}_{4}+$ MCP hydrates. Point - represents hydrate sample conditions before replacement.

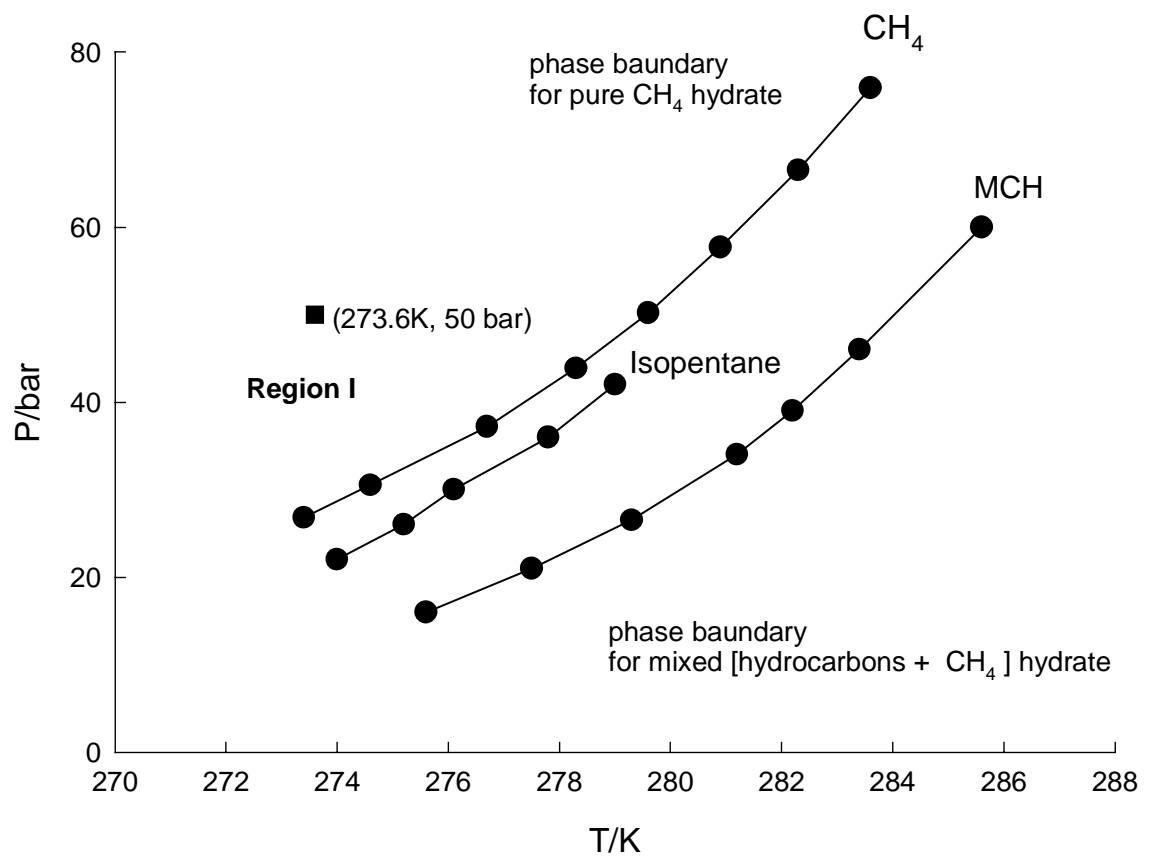


Figure S4-2. Phase diagram of $\mathrm{CH}_{4}, \mathrm{C}_{2} \mathrm{H}_{6}$, mixed $\mathrm{CH}_{4}+\mathrm{C}_{2} \mathrm{H}_{6}$ (feed gas : $\mathrm{C}_{2} \mathrm{H}_{6} 10$ mol\% balanced $\mathrm{CH}_{4}$ ), and mixed $\mathrm{CH}_{4}+\mathrm{C}_{2} \mathrm{H}_{6}$ (feed gas : $\mathrm{C}_{2} \mathrm{H}_{6} 20$ mol\% balanced $\mathrm{CH}_{4}$ ) hydrates

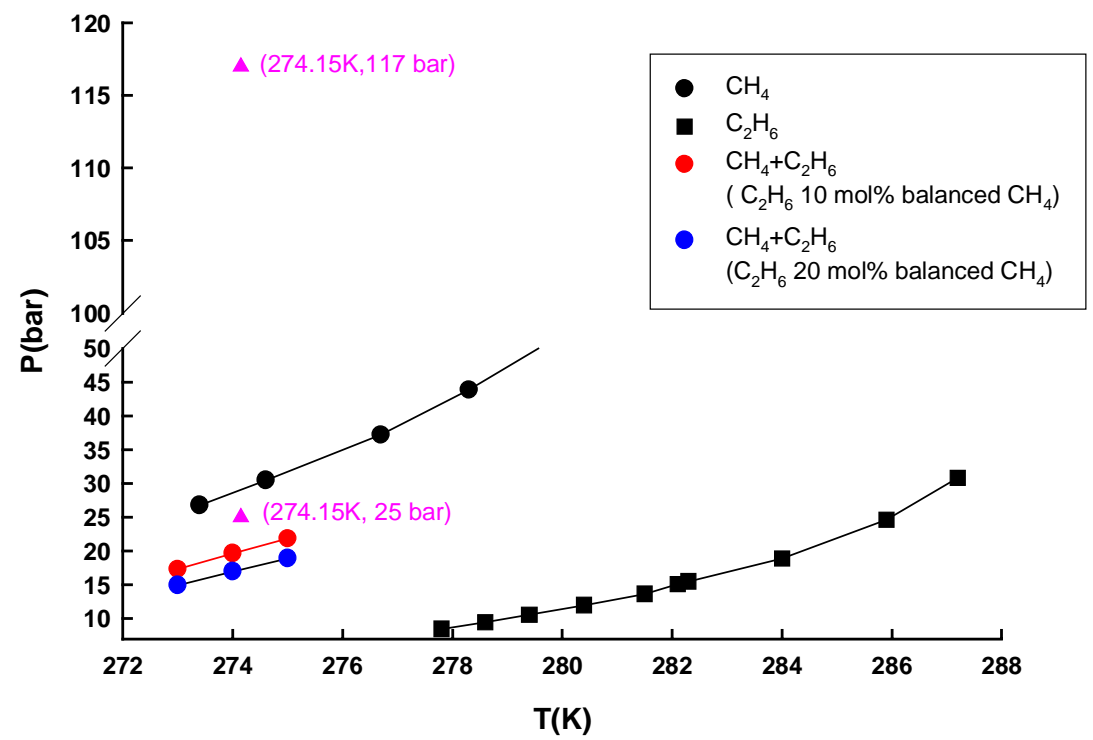




\section{Gas Chromatography}

The hydrate compositions were measured by analyzing the gases encaged in the hydrate structures. For composition measurement of dissociated gases from the hydrate phase, a sampling valve with a loop volume of $1 \mu \mathrm{L}$ was installed and connected to a gas chromatograph on-line. The gas chromatograph (HEWLETT PACKARD, 5890 Series II) used a thermal conductivity detector (TCD) with a carbosieve 100/120 1/8" SUS packed column (SUPELCO) and was preliminarily calibrated for $\mathrm{CH}_{4}$.

Table S5-1 Compositions before and after replacement in hydrate phase

\begin{tabular}{|c|c|c|c|}
\hline \multirow{2}{*}{$\begin{array}{l}\text { Feed Gas Rate } \\
\mathrm{CH}_{4}: \mathrm{C}_{2} \mathrm{H}_{6}(\%)\end{array}$} & \multicolumn{3}{|c|}{ Hydrate phase composition } \\
\hline & $\begin{array}{l}\text { Before replacement } \\
\qquad \mathrm{CH}_{4}: \mathrm{C}_{2} \mathrm{H}_{6}(\%)\end{array}$ & \multicolumn{2}{|c|}{$\begin{array}{l}\text { After replacement } \\
\mathrm{CH}_{4}: \mathrm{C}_{2} \mathrm{H}_{6}(\%)\end{array}$} \\
\hline $90: 10$ & $70: 30$ & $\begin{array}{l}25 \text { bar } \mathrm{CH}_{4} \\
117 \text { bar } \mathrm{CH}_{4}\end{array}$ & $\begin{array}{c}83: 17 \\
99.9: 0.1\end{array}$ \\
\hline $80: 20$ & $59: 41$ & $\begin{array}{l}25 \text { bar } \mathrm{CH}_{4} \\
117 \text { bar } \mathrm{CH}_{4}\end{array}$ & $\begin{array}{l}68: 32 \\
83: 17\end{array}$ \\
\hline
\end{tabular}

Table S5-2 Gas phase compositions after replacement

\begin{tabular}{c|cc}
\hline \multirow{2}{*}{$\begin{array}{c}\text { Feed Gas Rate } \\
\mathrm{CH}_{4}: \mathrm{C}_{2} \mathrm{H}_{6}(\%)\end{array}$} & \multicolumn{2}{|c}{ Gas phase composition } \\
\cline { 2 - 3 } & \multicolumn{2}{|c}{$\begin{array}{c}\text { After replacement } \\
\mathrm{CH}_{4}: \mathrm{C}_{2} \mathrm{H}_{6}(\%)\end{array}$} \\
\hline \multirow{2}{*}{$90: 10$} & 25 bar $\mathrm{CH}_{4}$ & $98.589: 1.411$ \\
& 117 bar $\mathrm{CH}_{4}$ & $99.99: 0.01$ \\
\hline \multirow{2}{*}{$80: 20$} & 25 bar $\mathrm{CH}_{4}$ & $98.047: 1.953$ \\
& $117{\mathrm{bar} \mathrm{CH}_{4}}^{2}$ & $98.5: 1.5$ \\
\hline
\end{tabular}

